\title{
Contribution of Organization of Turkic States Members to World Heritage at a Time of Cultural Convergence from the Past to the Future ${ }^{*}$
}

\section{Cengiz Buyar** \\ Uğur Ünal ${ }^{* * *}$}

\begin{abstract}
In its journey from ancient history, human society has brought along many cultural and architectural values or properties. Some of which have reached our days and some of which have not for various reasons. Cultural values that are part of the common history of mankind are called world heritage. Since 1972, UNESCO has included cultural and natural heritage sites that can be considered as common assets of all mankind in the World Heritage List and work to protect them.

UNESCO's work on the World Heritage List fulfils the important task of making the values that humanity is about to lose visible and permanent again. As of 2019, there are 1,121 cultural heritage sites on the UNESCO World Heritage List. In this study, the cultural and natural heritage of the countries belonging to the Organization of Turkic States has been discussed using statistical and descriptive analysis methods according to the ten main criteria defined by UNESCO. Thus, it aims to jointly examine the cultural and natural heritage of the Turkish world inscribed on the World Cultural Heritage List and to assess them from an awareness-raising perspective.
\end{abstract}

\section{Keywords}

Culture, World Heritage List, UNESCO, Turkic World, Organization of Turkic States.

\footnotetext{
Date of Arrival: 04 February 2020 - Date of Acceptance: 04 February 2021

You can refer to this article as follows:

Buyar, Cengiz, and Uğur Ünal. "Contribution of Organization of Turkic States Members to World Heritage at a Time of Cultural Convergence from the Past to the Future." bilig, no. 100, 2022, pp. 1-35.

"Assoc. Prof., Kyrgyz-Turkish Manas University, Faculty of Humanities, Department of History Bishkek / Kyrgyzstan ORCID: 0000-0002-0549-4463

cengiz.buyar@manas.edu.kg

“**Assoc. Prof., Kyrgyz-Turkish Manas University, Faculty of Communication, Department of Public Relations and Advertising - Bishkek / Kyrgyzstan ORCID: 0000-0003-0294-0082 ugur.unal@manas.edu.kg
} 


\section{Introduction}

"Heritage is our legacy from the past, what we live with today, and what we pass on to future generations.

Our cultural and natural heritage are both irreplaceable sources of life and inspiration." (whc.unesco.org)

Since humankind first appeared on the stage of history, he has built a living world of his own around him and struggled to leave traces that will carry his culture to future generations. The events that disturbed the international community regarding cultural heritage preservation have resulted in the popularization of the world heritage concept. The first event in history that was significant in that aspect occurred with the arrangement to build the Aswan Dam in Egypt. The valley where the Abu Simbel temple is located, an important work of the Ancient Egyptian Civilization, was in danger of submersion in water. Therefore, after eight years of work to save the Abu Simbel temple from submergence during the building of the Aswan Dam, the temple situated on the banks of Lake Nasser was relocated up the hill (Ürün 4).

With the aim of embracing the values that are accepted as the heritage of humanity as a shared history, promoting and transferring these values to posterity, UNESCO embraced "The Convention Concerning the Protection of World Cultural and Natural Heritage" in the 17th General Conference organized in Paris in 1972. As per this conference, a project was undertaken to prepare a "World Heritage List" containing natural and/or cultural properties guaranteed for protection by the government of the country they are located in and considered to have significance for the whole world.

With this project, UNESCO aimed at establishing international collaboration in preserving the humanity's shared heritage. The objective was set for promoting the natural and cultural properties having universal values and considered to be the common heritage of the whole humanity, raising awareness in society about embracing this universal heritage and to ensure collaboration necessary to conserve the cultural and natural values damaged or destroyed for various reasons (Yıldız \& Derman 5-7). 
Monuments, natural formations, and archeological sites of international significance and thus needing to be appreciated and preserved are given the status of World Heritage. Based on the heritage classifications identified by UNESCO, the world heritage is divided into three categories: cultural, natural, and mixed (both cultural and natural) heritage (Huang et al. 829). UNESCO aims to identify, preserve, and promote the notion of conserving the natural and cultural heritage deemed important for humanity. The term cultural heritage pertains to "monuments, the groups of building, and historical sites, archeological, ornamental, scientific, ethnological, or anthropological" value. Natural heritage connotes to "the unique formations which demonstrate physical, biological, and geological features; natural terrain of endangered species which consist of both animals and plants, and sites of scientific, conservational, or aesthetic value" (Somuncu \& Yiğit 2).

As far as a historical viewpoint is concerned, an awareness toward the protection of heritage in the international community and the process of forming of World Heritage Convention are known to have started with cultural heritage. It is also clear that natural heritage sites are represented to a lesser degree than cultural heritage sites. This study, therefore, aims at identifying the properties and attributes which have been bequeathed to humanity by Organization of Turkic States formed by Turkey, Azerbaijan, Kazakhstan, Kyrgyzstan, and Uzbekistan, and are in UNESCO's World Heritage List. However, intangible heritage was not included in the project, which covered only properties of tangible heritage.

The 1990 s, a time when the international system experienced a transition to a new era, was a period of great excitement for countries such as Turkey and those which just proclaimed their independence, including Azerbaijan, Kazakhstan, Kyrgyzstan, and Uzbekistan. While these leading players of the Turkic World were struggling to build their nation-states following their independence in an environment of reunion and reacquaintance for the Turkic world, they also started to develop bilateral and multilateral relations with one another (Erol \& Çelik 20).

In this context, the International Turkish Culture Organization (TURKSOY) was established by Azerbaijan, Kazakhstan, Kyrgyzstan, Turkey, Turkmenistan and Uzbekistan in 1993 for the following purposes. To enable Turkic countries and peoples of Turkish origin and speaking Turkish language 
to understand each other better; To show future generations that Turkish culture has an important place in the formation of all human civilization; To make people feel that it is necessary to protect, revive and develop the culture and art of the Turkish-speaking countries and peoples; In this way, to teach the young generations of the member countries the fundamentals of national culture and thus to establish mutual friendly contacts (turksoy. org.tr). However, priority should be given to the efforts to ensure the cultural integration of the Turkic world (Arslan 149-216). As for the activities it carries out within this framework, conducting effective studies in strengthening the cultural partnership between member countries can be mentioned. It is a cultural cooperation organization that contributes to the intercultural rapprochement process with its activities aimed at promoting Turkish culture. It functions as the UNESCO of the Turkish world. In addition to being an effective cultural diplomacy tool, it is an institution that serves for the development of world civilization and universal human values (Purtaş, Cultural Diplomacy 91-114). At same time first of all, an institutionalization was needed in regulating relations and some steps were taken in this direction. Activities on cultural relations between Turkey and the Turkic Republics, such as Turkish Cooperation and Development Agency (TIKA), Ministry of National Education (MEB), Higher Education Institution (YÖK), Ministry of Culture, Presidency of Religious Affairs, Turkish Radio and Television General Directorate (TRT), Yunus Emre Institute, etc. realized by national institutions (Çandarlı Şahin 7).

For these purposes, TURKSOY tries to strengthen the cultural interaction and communication between Turkic Republics and Turkic communities by organizing various scientific and artistic meetings in all fields of culture and art, from painting to music, from literature to fine arts, from theater to cinema. Working to promote and develop the beauty, originality and diversity of the rich Turkish culture, TURKSOY plays an important role in the rise of Turkish civilization and in its cooperation with other cultures. Today, political and economic cooperation between the Turkic republics has also gained momentum. TURKPA was established in Baku in 2009, which works for cooperation between parliamentary diplomacy and legislative bodies. In the same year, the establishment of the Organization of Turkic States for political integration between Turkic states came into question. TURKSOY, which is a cooperation initiative launched in the cultural field, 
has ensured the realization of these cooperation initiatives in the political field with its successful works. It is seen that the success achieved in the field of cultural integration paves the way for cooperation in political and economic fields (Akıllı 3-14).

As a product of a series of summits that lasted until 2010, the Organization of Turkic States, as of then the Cooperation Council of Turkic Speaking States (Ak1ll 14), was formed in 2009 under the Nakhchivan Agreement in the capacity of an international organization aimed at promoting comprehensive collaboration between Turkish speaking countries. It is the only official body incorporated to conserve the heritage of the Turkic World in all areas (Yilmaz 124).

The objectives of the Organization of Turkic States are stated in detail in the second article of the Nakhchivan Agreement which is the principal and constitutive document of the organization. 10th paragraph of this article states, "Supporting interaction between the press and media of the Parties toward the evaluation, promotion, and dissemination of the rich cultural and historical heritage of Turkic peoples." As pointed out in the said paragraph, it is the main principle of the Organization of Turkic States to establish cooperation to uncover the heritage of the Turkic World and make them available to all humanity.

It is also among the objectives of the project to raise awareness for transferring the said properties which strengthen universal values to future generations. Another objective set for the project is to determine the potential of the countries in the Organization of Turkic States in handing down their heritage to future generations, also taking into account the values included in UNESCO's World Heritage Tentative List. With such a formation, the study examines the issue through statistical and descriptive analysis method. With such systematics, this study has the potential to serve as a foundation for future, more comprehensive studies. In this context, as the values of the Turkic World are not limited to the countries of the Organization of Turkic States, it will prove highly beneficial to study the heritage of the Turkic World on a much broader landscape stretching from the Adriatic Sea to the Great Wall of China. 


\section{World Heritage Awareness and Its Value}

The "World Heritage List" incorporating the most significant examples of humanity's shared heritage demonstrates the richness of the world's history and the variety of its nature. Selected under different criteria, these sites have very important roles from historical, natural or scientific perspectives.

If a property meets one or more criteria on the following list, the Committee acknowledges the property as possessing exceptional universal value. Therefore, the properties to be nominated must (kvmgm.ktb.gov. $\operatorname{tr} / 11.12 .2019)$ :

I. represent a masterpiece of human creative genius;

II. exhibit a significant transaction of human values on architectural or technological developments as well as advancements in monumental arts, urban planning or landscape design, within a time period or a cultural region of the world;

III. bear a unique or at least exceptional testimony to a cultural tradition or a civilization - living or disappeared;

IV. be an outstanding example of a type of building, architectural or technological ensemble or landscape which illustrates a significant stage or stages in human history;

V. be an outstanding example of a traditional human settlement, landuse, or sea-use which is representative of a culture (or cultures), or human interaction with the environment, especially when it has become vulnerable under the impact of irreversible change;

VI. be directly or tangibly associated with events or living traditions, ideas, or beliefs, works of artistic or literary value having exceptional universal significance. (The Committee considers that this criterion should preferably be used in conjunction with other criteria);

VII. contain supreme natural phenomena or areas of exceptional natural beauty or aesthetic significance;

VIII. be outstanding examples representing major stages of earth's history, including the record of life, significant on-going geological processes in the development of landforms, or significant geomorphic or physiographic features; 
IX. be outstanding examples of significant on-going ecological and biological processes in the evolution and development of terrestrial, freshwater, coastal, and marine ecosystems and plant and animal communities;

X. contain the most remarkable and significant natural habitats for in-situ conservation of biological diversity, including endangered species of outstanding universal value from a scientific or conservational viewpoint.

The sites meeting criteria 1-6 are considered cultural heritage, those meeting criteria 7-10 are considered natural heritage, and those meeting at the minimum one criteria of both natural and cultural criteria are regarded as mixed heritage.

Following a series of processes starting with the application of member countries that agreed upon the convention to UNESCO and finalized with the assessment of applications by specialists from International Council on Monuments and Sites (ICOMOS) and International Union for Conservation of Nature (IUCN), the nominated properties are given this status in line with the decision of World Heritage Committee. As of 2019, 1121 cultural and natural heritage properties are registered in the UNESCO World Heritage List around the world; 869 of these are cultural, 213 are natural, and 39 are mixed (cultural/natural) properties. This number is increasing with each annual meeting held by the World Heritage Committee (kvmgm.ktb.gov.tr/11.12.2019). Table 1 shows the distribution of this heritage by region.

\section{Table 1}

Number of World Heritage Properties By Region

\begin{tabular}{ccccccc}
\hline Regions & Cultural & Natural & Mixed & Total & $\begin{array}{c}\text { Percentage } \\
(\mathbf{\%})\end{array}$ & $\begin{array}{c}\text { States } \\
\text { Parties }\end{array}$ \\
\hline $\begin{array}{c}\text { Arab League } \\
\text { Latin America } \\
\text { and the Caribbean }\end{array}$ & 78 & 5 & 3 & 86 & 7.67 & 18 \\
Africa & 53 & 38 & 5 & 96 & 8.56 & 35 \\
$\begin{array}{c}\text { Asia Pacific } \\
\text { Europe and North }\end{array}$ & 189 & 67 & 12 & 268 & 23.91 & 36 \\
America & 453 & 65 & 11 & 529 & 47.19 & 50 \\
\hline Total & $\mathbf{8 6 9}$ & $\mathbf{2 1 3}$ & $\mathbf{3 9}$ & $\mathbf{1 1 2 1}$ & $\mathbf{1 0 0}$ & $\mathbf{1 6 7}$ \\
\hline
\end{tabular}


As shown in Table 1, world heritage was found in five different parts of the world, including the Arab League, South America, and the Caribbean, Africa, Asia Pacific, and Europe and North America. Furthermore, based on 2019 data, the number of states housing the 1121 world heritage properties is 167 in total. The number of countries in the world is 236 , whereas, according to the United Nations (UN), it is acknowledged that there are 193 sovereign states. In such a case, it is highly significant that contributions are made to the world heritage in 167 out of 192 states as officially acknowledged by the UN. This can be viewed as an effort to maintain continuity in creating values and transferring these values to future generations throughout the world.

Another critical point is the numeric distribution of properties that make up the world heritage by different categories. The highest number of properties in world heritage has been found under the cultural category. Based on Table 1 , this number is $869 / 1121$. Under the natural category, the number of properties in the world states is $213 / 1121$. The number in the mixed category, on the other hand, is falling and is 39/1121 at the moment. From this distribution, we can infer that the world states seem to have reached a certain level in creating cultural value.

Authenticity and Integrity of Heritage

The concept of the common inheritance of humankind is used identically with the world heritage concept. Until today, the 'common heritage' concept has been used in various settings based on different partnerships (Kiper 118119):

- It has been used as an instrument of religion-based partnerships at times. The Aga Khan awards given to successful examples of Islamic architecture as 'common values of Islam' are examples of this.

- Sometimes, natural and cultural values are embraced at regional scales-common Heritage of the Balkan Countries, Mediterranean Common Heritage, etc.

- The concept of common heritage has also been used on a continental scale, like the principles for protecting European Cultural Heritage. In this framework, the Convention for the Protection of the Architectural Heritage of Europe has been established. 
- The concept of common heritage is most commonly used on a global scale.

Properties nominated to World Heritage under criteria 1-6 must fulfil the 'authenticity' conditions. The conditions of authenticity might vary relying on the variety of cultural heritage and the framework it is a part of. Thus, there is a tendency to evaluate the authenticity of cultural heritage within its cultural contexts (Şakacı 466-467). Frankly, depending on the cultural context and the type of cultural heritage, in order for the properties to provide the conditions of authenticity, they must have the following attributes truthfully and credibly (Ahunbay 131-132):

- Authenticity in form and design,

- Authenticity in materials and substance,

- Authenticity in use and function,

- Authenticity in traditions, techniques and management systems,

- Authenticity in location and setting,

- Language and other forms of intangible heritage,

- Spirit and feeling,

- Other internal and external factors.

Characteristics, for example spirit and feeling, are less likely to be suitable for practical applications of the authenticity conditions. Nonetheless, they are deemed essential measures of character and sense of place in communities that maintain traditional and cultural continuousness. The adoption of aforementioned sources provides a profound comprehension of the inherent social, historic, artistic, and scientific dimensions of cultural heritage. In this connection, it is vital to use all physical, written, oral, and figurative sources enabling us to have knowledge about the nature, specificities, significance, and history of the cultural heritage. To this end, the State Party initially needs to distinguish significant applicable elements of authenticity. The articulation of authenticity is supposed to demonstrate the level to which authenticity is in existence among each of these noteworthy factors.

With regard to authenticity, it is solely justifiable in unexceptional conditions in which the archaeological relics, historical constructions, or the districts necessitate the reconstruction. Reconstruction can solely be accepted if it is 
based on complete and detailed documentation (World Heritage Center 31 www.whc.unesco.org; Dünya Mirası Konvansiyonunun...).

In addition to authenticity, it is also crucial that the cultural properties proposed for World Heritage are well preserved, and their deterioration processes are under control. The whole of the properties which are nominated for being listed in the World Heritage List should actualize the conditions of 'integrity' (Ahunbay 133). 'Integrity' is a measure of the wholeness and intactness of the natural and/or cultural heritage and its attributes. Therefore, inspecting the conditions of integrity necessitates assessing the extent to which the property (World Heritage Center 32 www.whc.unesco.org):

a) includes all elements necessary to express its Outstanding Universal Value;

b) is of adequate size to ensure the complete representation of the features and processes which convey the property's significance;

c) suffers from adverse effects of development and/or neglect.

"The integrity includes the intangible aspects of the being as well as its physical state. The evaluation study carried out for this purpose is included in the application file as the "Integrity Report" (Ahunbay 133). In this framework, the aim is to include unique areas for the whole world that preserve their authenticity and integrity in this list and ensure a balanced distribution geographically. Member countries are advised not to nominate non-unique monuments or sites of local or national significance to the world heritage list.

Since the protection of works and sites of universal value is of global importance, the Convention's member states are expected to share this responsibility. Hence, great emphasis is placed on raising public awareness, creating a sound management system for this purpose, and pursuing continuous monitoring policies, especially in order not to lose exceptional universal values (Ahunbay 133-134).

Its structure that is open to improvement is one of the important features of the Convention. For instance, positions such as the introduction of new concepts, opening ways of cooperation with national non-governmental organizations, as well as the development of the criteria for the "universal exceptional value" concept over time, are considered essential in order to make the Convention fit the needs of the time (Başlar 49). 


\section{Contribution of Organization of Turkic States Members to World Heritage}

Organization of Turkic States functions as the umbrella organization of the Turkic World. Organization of Turkic States, as of then the Cooperation Council of Turkic Speaking States, was formed in 2009 in the capacity of an international organization aimed at promoting extensive cooperation between Turkic countries. The founding members of the Organization of Turkic States are Azerbaijan, Kazakhstan, Kyrgyzstan, and Turkey. Uzbekistan became a full member at the 10th anniversary of its foundation.

In addition to economic and political cooperation between the member countries, the Council supports cooperation in the fields of education, youth and sports, transportation, customs, tourism, diaspora, information and communication technologies, media and information.

As per the Nakhchivan Agreement of 3 October 2009 and the Istanbul Declaration of 16 September 2010, which are the constitutive documents of Organization of Turkic States, member states of Organization have embraced the principles and purposes of the United Nations Convention as well as other universally accepted principles granted by international law. The Organization of Turkic States, which has been an observer member of the Organization for Economic Cooperation since 2012, has been awarded by the United Nations World Tourism Organization (UNWTO), the United Nations Development Program (UNDP), the United Nations Southern Cooperation Office (UNOSSC), the United Nations Alliance of Civilizations (UNAOC), There are Memoranda of Understanding of Cooperation signed with the World Customs Organization, the Islamic Cooperation Organization and SESRIC. It is also in cooperation with the Organization of Turkic States, OSCE, BSEC, CICA, UNECE, UNESCO, ASEAN and TIKA.

In the preface to Nakhchivan Agreement, the member states acknowledge their commitment to the purposes and fundamentals of the United Nations Convention and defined the central purpose of the Organization of Turkic States as "expanding the extensive collaboration between Turkish-speaking states and contributing to regional and global peace and stability. The member states further expressed their commitment to core principles such 
as democracy, having respect to human rights, the rule of law and good governance. The collaboration within Organization of Turkic States is built on the basis of special solidarity stemming from a common history, identity between the member states, and the linguistic bond between Turkish speaking peoples" (www.turkkon.org/2019).

The study aimed at questioning both qualitative and quantitative values of the contribution of Organization of Turkic States members to world heritage and coming to a conclusion by taking both the values in the current list and those in the tentative list into consideration; thus, looking at the bigger picture by means of demonstrating the contribution of Organization of Turkic States members to humanity. For this purpose, the states in Table 1 were primarily distributed by the properties they have.

\section{Table 2}

Distribution of the Contribution of Organization of Turkic States Members to World Heritage

\begin{tabular}{|c|c|c|c|c|c|}
\hline \multirow{2}{*}{ No } & \multirow{2}{*}{ State } & \multirow{2}{*}{ Year } & \multirow{2}{*}{ Name of Heritage } & \multicolumn{2}{|c|}{ Selection Criteria } \\
\hline & & & & Cultural & Natural \\
\hline 1 & TR & 1985 & $\begin{array}{l}\text { Goreme National Park and the } \\
\text { Rock Sites of Cappadocia }\end{array}$ & I., III., V. & VII. \\
\hline 2 & TR & 1985 & $\begin{array}{l}\text { Great Mosque and Hospital of } \\
\text { Divriği }\end{array}$ & I. & \\
\hline 3 & TR & 1985 & Historic Areas of Istanbul & $\begin{array}{l}\text { I., II., III., } \\
\text { IV. }\end{array}$ & \\
\hline 4 & TR & 1986 & Hattusha: The Hittite Capital & $\begin{array}{l}\text { I., II., III., } \\
\text { IV. }\end{array}$ & \\
\hline 5 & TR & 1987 & Mount Nemrut & I., II., IV. & \\
\hline 6 & TR & 1988 & Hierapolis-Pamukkale & III., IV. & VII. \\
\hline 7 & TR & 1988 & Xanthos-Letoon & II., III. & \\
\hline 8 & TR & 1994 & City of Safranbolu & II., IV., VI. & \\
\hline 9 & $\mathrm{TR}$ & 1998 & Archaeological Site of Troy & II., III., VI. & \\
\hline 10 & $\mathrm{TR}$ & 2011 & $\begin{array}{l}\text { Selimiye Mosque and Its Social } \\
\text { Complex }\end{array}$ & I., IV. & \\
\hline 11 & $\mathrm{TR}$ & 2012 & Neolithic Site of Çatalhöyük & III., IV. & \\
\hline 12 & $\mathrm{TR}$ & 2014 & $\begin{array}{l}\text { Bursa and Cumalikızık: The Birth } \\
\text { of the Ottoman Empire }\end{array}$ & $\begin{array}{l}\text { I., II., IV., } \\
\text { VI. }\end{array}$ & \\
\hline
\end{tabular}


13 TR 2014 Pergamon and Its Multi-layered Cultural Landscape

I., II., III., IV., VI.

14 TR 2015 Diyarbakır Fortress and Hevsel IV. Gardens Cultural Landscape

15 TR 2015 Efes

III., IV., VI.

16 TR 2016 Archaeological Site of Ani

II., III., IV.

17 TR 2017 Aphrodisias

II., III., IV., VI

18 TR 2018 Göbekli Tepe

I., II., IV.

19 AZ 2000 Walled City of Baku with the Shirvan- IV. shah's Palace and Maiden Tower

20 AZ 2007 Gobustan Rock Art Cultural

III. Landscape

21 AZ 2019 Historic Centre of Sheki with the

II., V. Khan's Palace

KZ 2003 Mausoleum of Khoja Ahmed Yasawi

23 KZ 2004 Petroglyphs within the Archaeological Landscape of Tamgaly

24 KZ 2008 Saryarka - Steppe and Lakes of Northern Kazakhstan

IX., X.

25 KZ 2014 Silk Roads: the Routes Network of Chang' an-Tianshan Corridor *

II., III., V., VI.

26 KZ 2016 Western Tien-Shan * X.

27 KG 2009 Sulaiman-Too Sacred Mountain III., VI.

28 KG 2014 Silk Roads: the Routes Network of II., III., V., Chang' an-Tianshan Corridor * VI.

29 KG 2016 Western Tien-Shan * X.

30 UZ 1990 Itchan Kala III., IV., V.

31 UZ 1993 Historic Centre of Bukhara II., IV., VI.

32 UZ 2000 Historic Centre of Shakhrisyabz III., IV.

33 UZ 2001 Samarkand-Crossroad of Cultures I., II., IV. 34 UZ 2016 Western Tien-Shan * X.

Those marked with a star are considered as transboundary property.

Source: https://whc.unesco.org/en/list/ 
A significant archive of specimens of world history brought together, each with specific characteristics of its own, UNESCO World Heritage List contains 18 World Heritage Sites from Turkey as of 1 September 2019, 16 of which are cultural and 2 are mixed properties. There are 3 cultural heritage sites in Azerbaijan. Kazakhstan has 5 heritage sites 3 of which are cultural, and 2 are natural. Also, based on the definition of UNESCO, 2 of these heritage sites are transboundary properties. Kazakhstan has 3 heritage sites 1 of which is cultural, and 2 are natural. 2 of the heritage sites in Kyrgyzstan are transboundary properties. Uzbekistan has 5 heritage sites, 4 of which are cultural, and 1 is natural.

A property from Turkey first entered the world heritage list in 1985 (Akyol et al. 50-64). Finally, Göbekli Tepe entered the list in 2018 (http:// www.unesco.org.tr/Pages/125/122/UNESCO-Dünya-Miras1-Listesi). Examination of the distribution of the 18 properties included in the list so far indicates that properties number 1 and 6 are mixed, and all the others have cultural value. It was also found that six different cultural criteria were distributed to the properties. The only natural criterion in 2 properties under the mixed category is criteria 7 A property from Azerbaijan entered the world heritage list for the first time in 2000. The most recent entry of a property from Azerbaijan into the world heritage list in 2019. All three of these properties in Azerbaijan have cultural value. The first property from Kazakhstan entered in the world heritage list in 2003. Kazakhstan's most recent entry in the list was in 2016. While 2 of these 5 properties included in the list have natural value, the remaining 3 properties are only cultural. It has also been stated that the cultural property number 25 and the natural property number 26 in Table 2 from Kazakhstan are also transboundary properties. As shown in Table 2, of the 3 properties from Kyrgyzstan, which first entered the list in 2009, and finally in 2016, 2 have cultural, and 1 has natural value. Additionally, it has been stated that the cultural property number 28 and the natural property number 29 in Table 2 from Kyrgyzstan are also transboundary properties. Table 2 shows that one property from Uzbekistan entered the list for the first time in 1990, and the most recent entry was in 2016. Uzbekistan has entered the World Heritage List with 4 cultural and 1 natural property. In addition, it has been pointed out that the cultural property number 34 is a transboundary property. 
Table 3

Matrix of Contribution Organization of Turkic States Members To World Heritage

\begin{tabular}{|c|c|c|c|c|c|c|c|c|}
\hline \multirow{2}{*}{\multicolumn{2}{|c|}{ Category }} & \multirow{2}{*}{ Criterion } & \multicolumn{5}{|c|}{ Organization of Turkic States Members } & \multirow{2}{*}{ Total } \\
\hline & & & \multicolumn{5}{|c|}{ Turkey Azerbaijan Kazakhstan Uzbekistan Kyrgyzstan } & \\
\hline & $\mathbf{I}$ & $\begin{array}{l}\text { To represent a masterpiece of } \\
\text { human creative genius; }\end{array}$ & 9 & - & 1 & 1 & - & 11 \\
\hline & II & $\begin{array}{l}\text { To exhibit an important in- } \\
\text { terchange of human values, } \\
\text { over a span of time or within a } \\
\text { cultural area of the world, on } \\
\text { developments in architecture } \\
\text { or technology, monumental } \\
\text { arts, town-planning or land- } \\
\text { scape design; }\end{array}$ & 11 & 1 & 1 & 2 & 1 & 16 \\
\hline & III & $\begin{array}{l}\text { To bear a unique or at least } \\
\text { exceptional testimony to a cul- } \\
\text { tural tradition or to a civiliza- } \\
\text { tion which is living or which } \\
\text { has disappeared; }\end{array}$ & 11 & 1 & 4 & 2 & 1 & 19 \\
\hline $\begin{array}{l}\text { 폴 } \\
\text { 를 }\end{array}$ & IV & $\begin{array}{l}\text { To be an outstanding example } \\
\text { of a type of building, architec- } \\
\text { tural or technological ensem- } \\
\text { ble or landscape which illus- } \\
\text { trates (a) significant stage(s) in } \\
\text { human history; }\end{array}$ & 15 & 1 & 1 & 4 & 1 & 22 \\
\hline & $\mathbf{V}$ & $\begin{array}{l}\text { To be an outstanding exam- } \\
\text { ple of a traditional human } \\
\text { settlement, land-use, or sea- } \\
\text { use which is representative } \\
\text { of a culture (or cultures), or } \\
\text { human interaction with the } \\
\text { environment especially when } \\
\text { it has become vulnerable un- } \\
\text { der the impact of irreversible } \\
\text { change; }\end{array}$ & 1 & 1 & 1 & 1 & 1 & 5 \\
\hline & VI & $\begin{array}{l}\text { To be directly or tangibly } \\
\text { associated with events or liv- } \\
\text { ing traditions, with ideas, or } \\
\text { with beliefs, with artistic and } \\
\text { literary works of outstanding } \\
\text { universal significance. (The } \\
\text { Committee considers that this } \\
\text { criterion should preferably } \\
\text { be used in conjunction with } \\
\text { other criteria); }\end{array}$ & 6 & - & 1 & 1 & 2 & 10 \\
\hline
\end{tabular}




\begin{tabular}{|c|c|c|c|c|c|c|c|c|}
\hline \multirow{4}{*}{ 茪 } & VII & $\begin{array}{l}\text { To contain superlative natural } \\
\text { phenomena or areas of ex- } \\
\text { ceptional natural beauty and } \\
\text { aesthetic importance; }\end{array}$ & 2 & - & - & - & - & 2 \\
\hline & VIII & $\begin{array}{l}\text { To be outstanding examples } \\
\text { representing major stages } \\
\text { of earth's history, including } \\
\text { the record of life, significant } \\
\text { on-going geological processes } \\
\text { in the development of land- } \\
\text { forms, or significant geomor- } \\
\text { phic or physiographic features; }\end{array}$ & - & - & - & - & - & 0 \\
\hline & IX & $\begin{array}{l}\text { To be outstanding examples } \\
\text { representing significant on-go- } \\
\text { ing ecological and biological } \\
\text { processes in the evolution and } \\
\text { development of terrestrial, } \\
\text { fresh water, coastal and marine } \\
\text { ecosystems and communities } \\
\text { of plants and animals; }\end{array}$ & - & - & 1 & - & - & 1 \\
\hline & $\mathbf{X}$ & $\begin{array}{l}\text { To contain the most import- } \\
\text { ant and significant natural } \\
\text { habitats for in-situ conserva- } \\
\text { tion of biological diversity, } \\
\text { including those containing } \\
\text { threatened species of out- } \\
\text { standing universal value from } \\
\text { the point of view of science or } \\
\text { conservation. }\end{array}$ & - & - & 2 & 1 & 1 & 4 \\
\hline
\end{tabular}

The matrix in Table 3 shows that the only criterion which has not yet been met by a property in a Organization of Turkic States member is number VIII. It also indicates that 22 properties meet criterion IV, which is the highest, and 1 property meets criterion IX., which is the lowest.

When examined in detail, the matrix demonstrates that Organization of Turkic States members have 11 heritage properties under criterion I for "representing masterpieces of human creative genius, 16 heritage properties under criterion II covering architecture or technology, monumental arts, town-planning or landscape design"; 19 heritage properties under criterion III for "bearing a unique or at least exceptional testimony to a cultural tradition or a civilization", 22 heritage properties (buildings) under criterion IV for "illustrating (a) significant stage(s) in human history", 5 heritage properties under criterion $\mathrm{V}$ for "being an exceptionally excellent 
instance of a traditional human settlement, land-use, or sea-use", 10 heritage properties under criterion VI for "being directly or tangibly associated with living traditions, with ideas, or with beliefs, with artistic and literary works" and 2 heritage properties under criterion VII for "containing superlative natural phenomena or areas of extraordinary natural beauty and aesthetic significance". They also have 1 heritage property under criterion XI for "being outstanding examples representing significant on-going ecological and biological processes" and finally 4 heritage properties under criterion $\mathrm{X}$ for "containing the most significant and essential natural habitats for in-situ conservation of biological diversity".

From the distribution of criteria in the matrix, it is understood that Organization of Turkic States members have 40 different types of diversity for 10 criteria. Of the heritage properties of Organization of Turkic States, which appears to have left a heritage under each criterion, Western TienShan stands out. Western Tien-Shan is situated in the Tien-Shan mountain range, which is one of the largest in the world. It stretches along the borders of Uzbekistan, Kazakhstan, and Kyrgyzstan. Western Tien-Shan is located at an altitude between 700 and 4503 meters. It has been acknowledged as a world heritage housing incredibly rich biodiversity, exhibiting transboundary properties for its rich landscapes and as the most significant and outstanding natural habitat within the borders of Organization of Turkic States.

\section{Tentative List Period for the Contribution of Organization of Turkic States Members to World Heritage}

Alongside these heritage properties included in UNESCO World Heritage List, there is also a World Heritage Tentative List containing heritage properties being evaluated for inclusion in the list. The Tentative List serves as an inventory for member states, and the sites to be nominated for the official list are selected from this list. 1700 heritage properties from 178 state parties are included in UNESCO's World Heritage Tentative List.

A total of 78 heritage properties from Turkey made it to the tentative list, 73 of which are cultural, 2 are mixed, and 3 are natural, as initially submitted in 1994 and finally updated in 2019. The Tentative List also includes a total of 9 heritage properties from Azerbaijan (5 cultural and 4 natural), 13 heritage properties from Kazakhstan ( 5 cultural, 3 natural and 5 mixed), 2 heritage 
properties from Kyrgyzstan and 30 heritage properties from Uzbekistan (24 cultural, 3 natural and 3 mixed).

\section{Table 4}

Turkey's Tentative List For World Heritage

\begin{tabular}{|c|c|c|c|c|}
\hline No & State & $\begin{array}{l}\text { Application } \\
\text { Date }\end{array}$ & Name of Heritage Property & $\begin{array}{c}\begin{array}{c}\text { Selection } \\
\text { Criteria }\end{array} \\
\text { Cultural/ } \\
\text { Natural/Mixed } \\
\end{array}$ \\
\hline 1 & TR & 1994 & Aizanoi Antique City & II, IV \\
\hline 2 & TR & 2000 & Akdamar Church & I, II, III, IV \\
\hline 3 & TR & 2000 & Alahan Monastery & I., III., IV. \\
\hline 4 & TR & 2000 & Alanya & III, IV \\
\hline 5 & TR & 2000 & Anatolian Seljuks Madrasahs & II, IV \\
\hline 6 & TR & 2000 & $\begin{array}{l}\text { Ancient Cities of Lycian } \\
\text { Civilization }\end{array}$ & III, IV \\
\hline 7 & TR & 2000 & Ancient City of Anazarbos & III, IV, VI \\
\hline 8 & TR & 2000 & Ancient City of Kaunos & I, II, III, IV \\
\hline 9 & $\mathrm{TR}$ & 2000 & Ancient city of Kibyra & III, IV \\
\hline 10 & $\mathrm{TR}$ & 2000 & Ancient City of Korykos & II, III, IV \\
\hline 11 & TR & 2000 & Ancient City of Stratonikeia & II, IV \\
\hline 12 & TR & 2000 & $\begin{array}{l}\text { Archaeological Site of } \\
\text { Arslantepe }\end{array}$ & II, III, IV \\
\hline 13 & TR & & Archaeological Site of Assos & III, IV, VI \\
\hline 14 & TR & 2009 & $\begin{array}{l}\text { Archaeological Site of } \\
\text { Kültepe-Kanesh }\end{array}$ & II, III \\
\hline 15 & TR & 2009 & $\begin{array}{l}\text { Archaeological site of } \\
\text { Laodikeia }\end{array}$ & II, III, IV \\
\hline 16 & TR & 2011 & Archaeological Site of Perge & II \\
\hline 17 & TR & 2011 & Archaeological Site of Priene & II, III, IV, VI \\
\hline 18 & $\mathrm{TR}$ & 2012 & $\begin{array}{l}\text { Archaeological Site of } \\
\text { Sagalassos }\end{array}$ & II, III \\
\hline 19 & $\mathrm{TR}$ & 2012 & Archeological Site of Zeugma & II, III, IV \\
\hline 20 & $\mathrm{TR}$ & 2012 & Ayvalık Industrial Landscape & III, V \\
\hline 21 & $\mathrm{TR}$ & 2012 & $\begin{array}{l}\text { Basilica Therma (Sarıkaya } \\
\text { Roman Bath) }\end{array}$ & IV \\
\hline 22 & TR & 2012 & $\begin{array}{l}\text { Dardanelles and Gallipoli } \\
\text { Battle Zones in the First } \\
\text { World War }\end{array}$ & VI \\
\hline
\end{tabular}




\begin{tabular}{|c|c|c|c|c|}
\hline 23 & TR & 2012 & $\begin{array}{l}\text { Early Period of Anatolian } \\
\text { Turkish Heritage: Niksar, } \\
\text { The Capital of Danishmend } \\
\text { Dynasty }\end{array}$ & II, IV, VI \\
\hline 24 & TR & 2012 & Eflatun Pinar: The Hittite & III, IV, VI \\
\hline 25 & TR & 2012 & $\begin{array}{l}\text { Eshab-1 Kehf Kulliye } \\
\text { (Islamic-Ottoman Social } \\
\text { Complex) }\end{array}$ & III, VI \\
\hline 26 & TR & 2012 & Esrefoglu Mosque & II, IV \\
\hline 27 & TR & 2012 & Gordion & III, IV, VI \\
\hline 28 & TR & 2012 & $\begin{array}{l}\text { Güllük Dagi-Termessos } \\
\text { National Park }\end{array}$ & \\
\hline 29 & TR & 2013 & $\begin{array}{l}\text { Haci Bayram Mosque and its } \\
\text { Surrounding Area (the Haci } \\
\text { Bayram District) }\end{array}$ & IV, VI \\
\hline 30 & TR & 2013 & Haci Bektas Veli Complex & III, VI \\
\hline 31 & TR & 2013 & Harran and Sanliurfa & I, II, III, IV \\
\hline 32 & TR & 2014 & Hatay, St. Pierre Church & III, VI \\
\hline 33 & TR & 2014 & Historic City of Harput & III, IV, VI \\
\hline 34 & TR & 2014 & $\begin{array}{l}\text { Historic Guild Town of } \\
\text { Mudurnu }\end{array}$ & II, IV \\
\hline 35 & TR & 2014 & Historic Town of Birgi & II, IV \\
\hline 36 & TR & 2014 & $\begin{array}{l}\text { Historical Monuments of } \\
\text { Niğde }\end{array}$ & II \\
\hline 37 & TR & 2014 & Ishak Pasha Palace & I, III, IV \\
\hline 38 & TR & 2014 & $\begin{array}{l}\text { Ismail Fakirullah Tomb } \\
\text { and its Light Refraction } \\
\text { Mechanism }\end{array}$ & IV, VI \\
\hline 39 & TR & 2014 & Ivriz Cultural Landscape & II, III, IV \\
\hline 40 & TR & 2014 & İznik & II, III, V \\
\hline 41 & TR & 2014 & Karain Cave & III, VI \\
\hline 42 & TR & 2014 & Kekova & \\
\hline 43 & TR & 2014 & $\begin{array}{l}\text { Kizılirmak Delta Wetland } \\
\text { and Bird Sanctuary }\end{array}$ & VII, X \\
\hline 44 & TR & 2014 & $\begin{array}{l}\text { Konya-A capital of Seljuk } \\
\text { Civilization }\end{array}$ & I, II, IV \\
\hline 45 & TR & 2015 & $\begin{array}{l}\text { Lake Tuz Special } \\
\text { Environmental Protection } \\
\text { Area (SEPA) }\end{array}$ & VII, VIII, X \\
\hline 46 & TR & 2015 & Mahmut Bey Mosque & II, IV \\
\hline
\end{tabular}




\begin{tabular}{|c|c|c|c|c|}
\hline 47 & TR & 2015 & Mamure Castle & $\mathrm{IV}, \mathrm{V}$ \\
\hline 48 & TR & 2015 & Mardin Cultural Landscape & II, III, IV \\
\hline 49 & TR & 2015 & $\begin{array}{l}\text { Mausoleum and Sacred area } \\
\text { of Hecatomnus }\end{array}$ & I, III, IV \\
\hline 50 & TR & 2015 & Medieval City of Beçin & II \\
\hline 51 & TR & 2015 & $\begin{array}{l}\text { Mount Harşena and the } \\
\text { Rrock-tombs of the Pontic } \\
\text { Kings }\end{array}$ & III, VI, VII \\
\hline 52 & TR & 2015 & Mountainous Phrygia & II, III, IV \\
\hline 53 & TR & 2015 & Nature Park of Ballıca Cave & VII, VIII \\
\hline & TR & 2015 & Nuruosmaniye Complex & II, III, IV \\
\hline 55 & TR & 2016 & $\begin{array}{l}\text { Odunpazari Historical Urban } \\
\text { Site }\end{array}$ & III, VI \\
\hline 56 & TR & 2016 & $\begin{array}{l}\text { Seljuk Caravanserais on } \\
\text { the route from Denizli to } \\
\text { Dogubeyazit }\end{array}$ & II, III, IV \\
\hline 57 & TR & 2016 & Sivrihisar Great Mosque & II, IV \\
\hline 58 & TR & 2016 & St. Nicholas Church & III, IV \\
\hline 59 & TR & 2016 & $\begin{array}{l}\text { St.Paul Church, St.Paul's } \\
\text { Well and surrounding } \\
\text { historic quarters }\end{array}$ & II, III, IV \\
\hline 60 & TR & 2016 & $\begin{array}{l}\text { Sultan Bayezid II Complex: } \\
\text { A Center of Medical } \\
\text { Treatment }\end{array}$ & II, IV, VI \\
\hline 61 & TR & 2016 & $\begin{array}{l}\text { Sümela Monastery (The } \\
\text { Monastery of Virgin Mary) }\end{array}$ & I, III \\
\hline 62 & TR & 2016 & $\begin{array}{l}\text { The Ancient City of Sardis } \\
\text { and the Lydian Tumuli of } \\
\text { Bin Tepe }\end{array}$ & I, II, III \\
\hline 63 & TR & 2016 & The Bodrum Castle & II, III, IV \\
\hline 64 & TR & 2017 & The Bridge of Justinian & III, IV \\
\hline 65 & TR & 2017 & The Bridge of Uzunköprü & III, IV \\
\hline 66 & TR & 2017 & The Malabadi Bridge & III, IV, VI \\
\hline 67 & TR & 2018 & $\begin{array}{l}\text { The Theatre and Aqueducts } \\
\text { of the Ancient City of } \\
\text { Aspendos }\end{array}$ & I, II, IV \\
\hline 68 & TR & 2018 & $\begin{array}{l}\text { The Tombstones of Ahlat } \\
\text { the Urartian and Ottoman } \\
\text { citadel }\end{array}$ & I, III \\
\hline 69 & TR & 2018 & $\begin{array}{l}\text { The Underground Water } \\
\text { Structures in Gaziantep; } \\
\text { Livas' and Kastels }\end{array}$ & III, IV \\
\hline
\end{tabular}




\begin{tabular}{|c|c|c|c|c|}
\hline 70 & TR & 2018 & Tomb of Ahi Evran & III, VI \\
\hline 71 & TR & 2018 & $\begin{array}{l}\text { Trading Posts and } \\
\text { Fortifications on Genoese } \\
\text { Trade Routes from the } \\
\text { Mediterranean to the Black } \\
\text { Sea }\end{array}$ & II, IV \\
\hline 72 & TR & 2018 & $\begin{array}{l}\text { Tushpa/Van Fortress, the } \\
\text { Mound and the Old City of } \\
\text { Van }\end{array}$ & II, III, IV, VI \\
\hline 73 & TR & 2018 & Vespasianus Titus Tunnel & I, IV \\
\hline 74 & TR & 2013 & $\begin{array}{l}\text { Wooden Roofed and } \\
\text { Wooden Columned Mosques } \\
\text { in Anatolia }\end{array}$ & II, IV \\
\hline 75 & TR & 2016 & $\begin{array}{l}\text { Yesemek Quarry and } \\
\text { Sculpture Workshop }\end{array}$ & II, III \\
\hline 76 & TR & 2019 & Yivli Minaret Mosque & II, IV \\
\hline 77 & TR & 2000 & Yildız Palace Complex & II, III, IV \\
\hline 78 & TR & 2000 & $\begin{array}{l}\text { Zeynel Abidin Mosque } \\
\text { Complex and Mor Yakup } \\
\text { (Saint Jacob) Church }\end{array}$ & III, IV \\
\hline
\end{tabular}

Source: https://whc.unesco.org/en/tentativelists/state=tr.

The first six of the criteria for the above properties of heritage to be left to humanity are cultural, and criteria seven to ten are natural. Examination of the distribution of (78) properties in Turkey's World Heritage Tentative List in Table 4 above by selection criteria indicates that a vast majority of properties have cultural value. Only properties 43, 45, and 53 meet the natural criteria. 


\section{Table 5}

Azerbaijan's Tentative List For World Heritage

\begin{tabular}{|c|c|c|c|c|}
\hline No & State & $\begin{array}{l}\text { Application } \\
\text { Date }\end{array}$ & Name of Heritage Property & $\begin{array}{c}\begin{array}{c}\text { Selection } \\
\text { Criteria }\end{array} \\
\text { Cultural/ } \\
\text { Natural/Mixed }\end{array}$ \\
\hline 1 & $\mathrm{AZ}$ & $30 / 09 / 1998$ & "Baku Stage" Mountain & VII, IX \\
\hline 2 & $\mathrm{AZ}$ & $30 / 09 / 1998$ & $\begin{array}{l}\text { "Binegadi" 4th Period Fau- } \\
\text { na and Flora Deposit }\end{array}$ & VIII, IX \\
\hline 3 & $\mathrm{AZ}$ & $30 / 09 / 1998$ & "Lok-Batan” Mud Cone & VII, VIII, IX \\
\hline 4 & $\mathrm{AZ}$ & $30 / 09 / 1998$ & Hyrkan State Reservation & VII, X \\
\hline 5 & $\mathrm{AZ}$ & $24 / 10 / 2001$ & $\begin{array}{l}\text { Ordubad historical and } \\
\text { architectural reserve }\end{array}$ & $\mathrm{I}, \mathrm{IV}, \mathrm{V}$ \\
\hline 6 & $\mathrm{AZ}$ & $30 / 09 / 1998$ & $\begin{array}{l}\text { Surakhany, Atashgyakh } \\
\text { (Fire - worshippers, temple } \\
\text { - museum at Surakhany) }\end{array}$ & I, III \\
\hline 7 & $\mathrm{AZ}$ & $24 / 10 / 2001$ & $\begin{array}{l}\text { Susha historical and archi- } \\
\text { tectural reserve }\end{array}$ & $\mathrm{I}, \mathrm{IV}, \mathrm{V}, \mathrm{VI}$ \\
\hline 8 & AZ & $24 / 10 / 2001$ & $\begin{array}{l}\text { The Caspian Shore Defen- } \\
\text { sive Constructions }\end{array}$ & \\
\hline 9 & AZ & $30 / 09 / 1998$ & $\begin{array}{l}\text { The mausoleum of Nakh- } \\
\text { ichevan }\end{array}$ & I, IV \\
\hline
\end{tabular}

Source: https://whc.unesco.org/en/tentativelists/state=az.

A member state of the Organization of Turkic States, Azerbaijan has 9 properties in World Heritage Tentative List. These properties appear to meet all criteria both natural and cultural, except for selection criterion II. Table 5 shows that the application was made for these properties between the years 1998 and 2001. The number of properties that entered the Tentative List was 6 in 1998 and 3 in 2001. 


\section{Table 6}

Kazakhstan's Tentative List For World Heritage

\begin{tabular}{|c|c|c|c|c|}
\hline No & State & $\begin{array}{l}\text { Application } \\
\text { Date }\end{array}$ & Name of Heritage Property & $\begin{array}{c}\begin{array}{c}\text { Selection } \\
\text { Criteria }\end{array} \\
\text { Cultural/ } \\
\text { Natural/Mixed } \\
\end{array}$ \\
\hline 1 & $\mathrm{KZ}$ & $06 / 02 / 2002$ & $\begin{array}{l}\text { Aksu-Zhabagly state natural } \\
\text { reserve }\end{array}$ & VII, X \\
\hline 2 & $\mathrm{KZ}$ & 24/09/1998 & $\begin{array}{l}\text { Archaeological sites of Otrar } \\
\text { oasis }\end{array}$ & III, IV \\
\hline 3 & $\mathrm{KZ}$ & 24/09/1998 & $\begin{array}{l}\text { Barrows with stone ranges } \\
\text { of the Tasmola culture }\end{array}$ & \\
\hline 4 & $\mathrm{KZ}$ & 24/09/1998 & $\begin{array}{l}\text { Cultural landscape of Uly- } \\
\text { tau }\end{array}$ & \\
\hline 5 & $\mathrm{KZ}$ & 24/09/1998 & $\begin{array}{l}\text { Megalithic mausolea of the } \\
\text { Begazy-Dandybai culture }\end{array}$ & II, III, IV \\
\hline 6 & $\mathrm{KZ}$ & $06 / 02 / 2002$ & $\begin{array}{l}\text { Northern Tyan-Shan (Ile- } \\
\text { Alatau State National Park) }\end{array}$ & $\mathrm{X}$ \\
\hline 7 & $\mathrm{KZ}$ & $24 / 09 / 1998$ & $\begin{array}{l}\text { Paleolithic sites and geo- } \\
\text { morphology of Karatau } \\
\text { mountain range }\end{array}$ & \\
\hline 8 & $\mathrm{KZ}$ & $10 / 06 / 2016$ & $\begin{array}{l}\text { Petroglyph Site of Sauys- } \\
\text { kandyk (XVIII BC - III } \\
\text { AD) }\end{array}$ & II, III, IV \\
\hline 9 & $\mathrm{KZ}$ & 24/09/1998 & Petroglyphs of Arpa-Uzen & II, III, IV \\
\hline 10 & $\mathrm{KZ}$ & 24/09/1998 & Petroglyphs of Eshkiolmes & \\
\hline 11 & $\mathrm{KZ}$ & $03 / 05 / 2012$ & Silk Road & II, III, IV, V, VI \\
\hline 12 & $\mathrm{KZ}$ & $06 / 02 / 2002$ & $\begin{array}{l}\text { State National Natural Park } \\
\text { "Altyn-Emel" }\end{array}$ & VII, VIII, IX \\
\hline 13 & $\mathrm{KZ}$ & 24/09/1998 & Turkic sanctuary of Merke & \\
\hline
\end{tabular}

Source: https://whc.unesco.org/en/tentativelists/state=kz.

Table 6 shows the properties included in the Tentative List For World Heritage by Kazakhstan. This tentative list contains 13 properties. Selection criteria indicate that both natural and cultural values are distributed on average. Kazakhstan initially applied for 8 properties in 1998 and this was 
followed by another application for 2 properties in 2002 and another 2 in 2012 and 2016 for 1 property each.

\section{Table 7}

Kyrgyzstan's Tentative List For World Heritage

\begin{tabular}{ccclc}
\hline No & State & $\begin{array}{c}\text { Application } \\
\text { Date }\end{array}$ & Name of Heritage Property & $\begin{array}{c}\text { Selection } \\
\text { Criteria }\end{array}$ \\
\hline 1 & KG & $29 / 01 / 2001$ & $\begin{array}{l}\text { Cultural/ } \\
\text { Natural/Mixed }\end{array}$ \\
\hline 2 & KG & $19 / 02 / 2010$ & $\begin{array}{l}\text { Silk Roads Sites in Kyrgyz- } \\
\text { stan }\end{array}$ & II, III, IV, V, VI \\
\hline
\end{tabular}

Source: https://whc.unesco.org/en/tentativelists/state=kg.

As shown in Table 7, Kyrgyzstan has applied to the World Heritage Tentative List for 2 properties. Its initial application in 2001 was followed by the second application in 2010. Based on the selection criteria, both applications are in the cultural category.

\section{Table 8}

Uzbekistan's Tentative List For World Heritage

\begin{tabular}{|c|c|c|c|c|}
\hline \multirow{2}{*}{ No } & \multirow{2}{*}{ State } & \multirow{2}{*}{$\begin{array}{l}\text { Application } \\
\text { Date }\end{array}$} & \multirow{2}{*}{ Name of Heritage Property } & \multirow{2}{*}{$\begin{array}{c}\begin{array}{c}\text { Selection } \\
\text { Criteria }\end{array} \\
\text { Cultural/ } \\
\text { Natural/Mixed }\end{array}$} \\
\hline & & & & \\
\hline 1 & $\mathrm{UZ}$ & $18 / 01 / 2008$ & Abdulkhan Bandi Dam & IV \\
\hline 2 & $\mathrm{UZ}$ & $18 / 01 / 2008$ & Ahsiket & I, II, III, IV \\
\hline 3 & $\mathrm{UZ}$ & $01 / 06 / 1996$ & $\begin{array}{l}\text { Ak Astana-baba (mausole- } \\
\text { um) }\end{array}$ & I, II, III \\
\hline 4 & $\mathrm{UZ}$ & $18 / 01 / 2008$ & Ancient Pap & I, II, IV \\
\hline 5 & $\mathrm{UZ}$ & $18 / 01 / 2008$ & Ancient Termiz & $\begin{array}{l}\text { I, II, III, IV, V, } \\
\text { VI, IX }\end{array}$ \\
\hline 6 & $\mathrm{UZ}$ & $18 / 01 / 2008$ & Andijon & III, IV, V \\
\hline 7 & $\mathrm{UZ}$ & $18 / 01 / 2008$ & Arab-Ata Mausoleum & II \\
\hline 8 & $\mathrm{UZ}$ & $18 / 01 / 2008$ & $\begin{array}{l}\text { Bahoutdin Architectural } \\
\text { Complex }\end{array}$ & IV \\
\hline 9 & $\mathrm{UZ}$ & $18 / 01 / 2008$ & Boysun & IV, V, VII, IX \\
\hline
\end{tabular}




\begin{tabular}{|c|c|c|c|c|}
\hline 10 & UZ & $18 / 01 / 2008$ & Chashma-Ayub Mausoleum & II \\
\hline 11 & $\mathrm{UZ}$ & $18 / 01 / 2008$ & Chor-Bakr & IV \\
\hline 12 & $\mathrm{UZ}$ & $01 / 06 / 1996$ & $\begin{array}{l}\text { Complex of Sheikh } \\
\text { Mukhtar-Vali (mausoleum) }\end{array}$ & I, II, III \\
\hline 13 & $\mathrm{UZ}$ & $18 / 01 / 2008$ & $\begin{array}{l}\text { Desert Castles of Ancient } \\
\text { Khorezm }\end{array}$ & $\begin{array}{l}\text { I, II, III, IV, } \\
\text { V, VI }\end{array}$ \\
\hline 14 & UZ & $18 / 01 / 2008$ & Gissar Mountains & VII, VIII, X \\
\hline 15 & $\mathrm{UZ}$ & $18 / 01 / 2008$ & Historic Center of Qoqon & II \\
\hline 16 & $\mathrm{UZ}$ & $18 / 01 / 2008$ & Kanka & II, III, IV, VI \\
\hline 17 & $\mathrm{UZ}$ & $01 / 06 / 1996$ & Khanbandi (dam) & I, II, III \\
\hline 18 & $\mathrm{UZ}$ & $18 / 01 / 2008$ & Khazarasp & I, II, III, IV, V \\
\hline 19 & $\mathrm{UZ}$ & $18 / 01 / 2008$ & Minaret in Vobkent & I, II, III \\
\hline 20 & $\mathrm{UZ}$ & $18 / 01 / 2008$ & $\begin{array}{l}\text { Mir-Sayid Bakhrom Mau- } \\
\text { soleum }\end{array}$ & III \\
\hline 21 & $\mathrm{UZ}$ & $18 / 01 / 2008$ & Poykent & II, III, IV, VI \\
\hline 22 & $\mathrm{UZ}$ & $18 / 01 / 2008$ & Rabati Malik Caravanserai & $\begin{array}{l}\text { I, II, III, IV, } \\
\text { V, VI }\end{array}$ \\
\hline 23 & $\mathrm{UZ}$ & $18 / 01 / 2008$ & Sarmishsay & VI, IX \\
\hline 24 & $\mathrm{UZ}$ & $18 / 01 / 2008$ & Shahruhiya & II, III, IV, VI \\
\hline 25 & $\mathrm{UZ}$ & $18 / 01 / 2008$ & Shokhimardon & IX, X \\
\hline 26 & $\mathrm{UZ}$ & $19 / 02 / 2010$ & $\begin{array}{l}\text { Silk Roads Sites in Uzbeki- } \\
\text { stan }\end{array}$ & II, III, IV, V, VI \\
\hline 27 & $\mathrm{UZ}$ & $18 / 01 / 2008$ & Siypantosh Rock Paintings & II, III \\
\hline 28 & $\mathrm{UZ}$ & $18 / 01 / 2008$ & Varakhsha & $\mathrm{IV}, \mathrm{V}$ \\
\hline 29 & $\mathrm{UZ}$ & $18 / 01 / 2008$ & Zaamin Mountains & VIII, IX, X \\
\hline 30 & $\mathrm{UZ}$ & $18 / 01 / 2008$ & Zarautsoy Rock Paintings & I, II, III \\
\hline
\end{tabular}

Source: https://whc.unesco.org/en/tentativelists/state=uz.

Uzbekistan's applications in Table 8 show that Uzbekistan is in the tentative list with 30 properties. Uzbekistan applied to World Heritage Tentative List for 3 properties in 1996, 26 properties in 2008, and 1 property in 2010. The distribution by selection criteria in Table 8 shows that the applications were made for properties that have cultural, natural, and mixed value. 


\section{Table 9}

Matrix of the Tentative Lists of Organization of Turkic States Members

\begin{tabular}{|c|c|c|c|c|c|c|c|c|}
\hline \multirow{2}{*}{\multicolumn{2}{|c|}{ Category }} & \multirow{2}{*}{ Criterion } & \multicolumn{5}{|c|}{ Organization of Turkic States Members } & \multirow{2}{*}{ Total } \\
\hline & & & \multicolumn{5}{|c|}{ Turkey Azerbaijan Kazakhstan Uzbekistan Kyrgyzstan } & \\
\hline & I & $\begin{array}{l}\text { To represent a masterpiece of } \\
\text { human creative genius; }\end{array}$ & 12 & 4 & 1 & 14 & - & 31 \\
\hline & II & $\begin{array}{l}\text { To exhibit an important inter- } \\
\text { change of human values, over a } \\
\text { span of time or within a cultural } \\
\text { area of the world, on develop- } \\
\text { ments in architecture or technolo- } \\
\text { gy, monumental arts, town-plan- } \\
\text { ning or landscape design; }\end{array}$ & 40 & - & 4 & 19 & 1 & 64 \\
\hline & III & $\begin{array}{l}\text { To bear a unique or at least } \\
\text { exceptional testimony to } \\
\text { a cultural tradition or to a } \\
\text { civilization which is living or } \\
\text { which has disappeared; }\end{array}$ & 49 & 1 & 5 & 17 & 2 & 74 \\
\hline 苞 & IV & $\begin{array}{l}\text { To be an outstanding example } \\
\text { of a type of building, architec- } \\
\text { tural or technological ensem- } \\
\text { ble or landscape which illus- } \\
\text { trates (a) significant stage(s) in } \\
\text { human history; }\end{array}$ & 54 & 3 & 4 & 16 & 2 & 79 \\
\hline & $\mathbf{V}$ & $\begin{array}{l}\text { To be an outstanding example } \\
\text { of a traditional human set- } \\
\text { tlement, land-use, or sea-use } \\
\text { which is representative of a } \\
\text { culture (or cultures), or human } \\
\text { interaction with the environ- } \\
\text { ment especially when it has } \\
\text { become vulnerable under the } \\
\text { impact of irreversible change; }\end{array}$ & 3 & 2 & 1 & 8 & 1 & 15 \\
\hline & VI. & $\begin{array}{l}\text { To be directly or tangibly as- } \\
\text { sociated with events or living } \\
\text { traditions, with ideas, or with } \\
\text { beliefs, with artistic and literary } \\
\text { works of outstanding universal } \\
\text { significance. (The Committee } \\
\text { considers that this criterion } \\
\text { should preferably be used in } \\
\text { conjunction with other criteria); }\end{array}$ & 21 & 1 & 1 & 8 & 2 & 33 \\
\hline
\end{tabular}




\begin{tabular}{|c|c|c|c|c|c|c|c|c|}
\hline & VII. & $\begin{array}{l}\text { To contain superlative natural } \\
\text { phenomena or areas of ex- } \\
\text { ceptional natural beauty and } \\
\text { aesthetic importance; }\end{array}$ & 4 & 3 & 2 & 2 & - & 11 \\
\hline & VIII. & $\begin{array}{l}\text { To be outstanding examples } \\
\text { representing major stages } \\
\text { of earth's history, including } \\
\text { the record of life, significant } \\
\text { on-going geological pro- } \\
\text { cesses in the development } \\
\text { of landforms, or significant } \\
\text { geomorphic or physiographic } \\
\text { features; }\end{array}$ & 2 & 2 & 1 & 2 & - & 7 \\
\hline Z & IX. & $\begin{array}{l}\text { To be outstanding exam- } \\
\text { ples representing significant } \\
\text { on-going ecological and } \\
\text { biological processes in the } \\
\text { evolution and development of } \\
\text { terrestrial, fresh water, coastal, } \\
\text { and marine ecosystems and } \\
\text { communities of plants and } \\
\text { animals; }\end{array}$ & - & 3 & 1 & 5 & - & 9 \\
\hline & $\mathbf{X}$ & $\begin{array}{l}\text { To contain the most import- } \\
\text { ant and significant natural } \\
\text { habitats for in-situ conserva- } \\
\text { tion of biological diversity, } \\
\text { including those containing } \\
\text { threatened species of out- } \\
\text { standing universal value from } \\
\text { the point of view of science or } \\
\text { conservation. }\end{array}$ & 2 & 1 & 2 & 3 & - & 8 \\
\hline
\end{tabular}

Table 9 shows the extent of the contribution made by Organization of Turkic States Members to the World Heritage Tentative List. It is clear these states leave heritage under each criterion. As shown in the table, Organization of Turkic States Members have applied to the Tentative List for 31 properties under criteria I, 64 properties under criteria II, 74 properties under criteria III, 79 properties under criteria IV, 15 properties under criteria V, 33 properties under criteria VI, 11 properties under criteria VII, 7 properties under criteria VIII, 9 properties under criteria IX and 8 properties under criteria X. With their heritage under every criterion, the extent of their contribution to world heritage is evident. 
Based on the matrix, the diversity of criteria that the properties in the Organization of Turkic States Tentative List fall under deserves attention, with criteria distribution at a diversity of 331 in total. The matrix shows that 282 of this diversity is under criteria I, II, III, IV, and VI. When examined in detail, these criteria demonstrate that Organization of Turkic States members abundantly and intensively possess properties that have the quality of representing masterpieces of human creative genius; involving architectural or technological designs, monumental arts, urban planning or landscape design elements; bearing a unique, exceptional testimony to a cultural tradition or a civilization; being a building illustrating a significant stage or several stages in human history; directly or tangibly associated with living traditions, ideas, or beliefs, or works with artistic and literary value.

\section{Conclusion}

It is a fact that today, the significance of culture and history of local sites increases as they are influenced by globalization. Therefore, it is better to view them as places where people come to discover their own identities.

This study, which was carried out precisely for this purpose, bears great significance regarding the formation of a collective consciousness towards the conservation of the cultural heritage of the Turkic World. The Organization of Turkic States members have been home to many civilizations. A landscape where different schools of wisdom, artistic movements, and religions have emerged, mixed, and spread around, Central Asia, Caucasia, and Anatolia are lands of a cultural mosaic. The cultural heritage of these civilizations handed down from generation to generation has also become an important tool for publicity. Cultural heritage, which is the purest expression of the culture of a society, not only demonstrates the relations of that culture with its surrounding region but reflects the cultural diversity of the world at the same time (Horata 127). Also heritage education should be included in teacher training to inform teachers about heritage and its educational value (Dönmez \& Yeşilbursa 425-442).

Central Asia, which has a very rich cultural heritage that the Turkish-Islamic civilization brought to the world civilization and humanity, lived its golden periods in the Middle Ages when the Silk Road was alive (Purtaş 10, Işıktaş \& Duran 584-596). Today, those who think on issues such as re-launching 
the Silk Road and opening it to international trade make geopolitical and geostrategic initiatives and describe future scenarios (Taşağıl 2294). At the Fourth Summit of the Organization of Turkic States held in 2014, a decision was taken to develop a common product in the field of tourism. Then, "Organization of Turkic States Silk Road Joint Tour Package" studies were started in this direction. The project was designed to raise global awareness about the historical and cultural significance of the Silk Road, which stretches across the Organization of Turkic States member countries and the wider geography. It is very important in terms of bringing the natural and cultural heritage elements of Turkish countries to tourism at national, regional and international level (Deniz \& Karadağ 96). In the project where the first tour was held in 2018, it was aimed to recognize the Turkish World, to create its advertisement and image at the international level. Uzbekistan and Turkmenistan's participation is expected in a short time, "Grand Package" also known by the name of the tour, currently in Turkey - Azerbaijan Kazakhstan - Kyrgyzstan covers (http://www.modernsilkroadtour.com). However, heritage tourism is gaining importance day by day (Aliağaoğlu 51-53). It is also seen that the interest of tourists is much higher in the areas on the World Heritage List (Poria et al. 162-178, Edson 133).

Based on the results of our study, it can be asserted that Organization of Turkic States made up of Turkey, Azerbaijan, Kazakhstan, Kyrgyzstan, and Uzbekistan show an increased awareness in promoting the cultural and natural properties in within their borders with universal values and considered to be the common heritage of the whole humanity, also raising awareness in society about embracing this universal heritage and to ensure collaboration necessary to conserve the cultural and natural values damaged or destroyed for various reasons. With properties that meet a total of 10 criteria (6 cultural and 4 natural) set by UNESCO for World Heritage, Organization of Turkic States members have contributed to the World Heritage List with 34 properties in total.

In fact, it is evident that the properties of Organization of Turkic States members in the World Heritage List contribute to the memory of the world and bridging cultural differences to a considerable extent. For instance, Gobustan Rock Art Cultural Landscape in Azerbaijan is an extraordinary collection with more than 6000 engravings bearing a 10.000-year testimony 
to rock art. Silk Roads: the Routes Network of Chang' an-Tianshan Corridor within the borders of Kazakhstan and Kyrgyzstan is a $5000 \mathrm{~km}$ part of the vast network of Silk Roads stretching from Chang' an/Luoyang, Chinese capital during Han and Tang dynasties, to the Zhetysu region in Central Asia. It was formed between the 2nd century BC and 1 st century AD and was actively used until the 16 th century, connecting various civilizations. It facilitated large-scale interchange activities in commerce, religious beliefs, scientific knowledge, technological advancements, and cultural practices. As another example, Sulayman Mountain in the city of Osh in Kyrgyzstan is an important historical, geographical and sacred site illustrating the cultural layers of the entire human history (Buyar 13-42). Göbekli Tepe archeological site in Turkey is now considered to be the most important heritage site of all human history and referred to as zero point in time with its history of 12 thousand years. Göbekli Tepe attracts more attention every day as a heritage site changing everything we knew about the lives and belief systems of the prehistoric hunter-gatherer groups. Samarkand in Uzbekistan is defined as a crossroad of world cultures (https://whc.unesco.org/en/). Since it is located on the Silk Road which has an important place in history, it served as one of the most important centers for commercial and social life. The palace, mosques, madrasahs, and mausoleums in the city date back to hundreds of years ago. Most of these works are covered with blue tiles.

The tentative list figures indicate that the quantity of properties on the World Heritage List will soon increase further. Based on the findings of the study, while Turkey has 78 properties in the World Heritage Tentative List, Azerbaijan has 9, Kazakhstan has 13, Kyrgyzstan has 2 and Uzbekistan has 30 properties. In this context, Organization of Turkic States members have applied for a total of 132 properties in the World Heritage Tentative List. The distribution of cultural, natural, and mixed value in these properties and their contribution to world heritage is meaningful and indisputably significant.

From this perspective, Organization of Turkic States appears to play a significant role in completing the cultural inventory in terms of conserving the cultural heritage of the Turkic World and transferring it to the World Heritage as well as in mapping the heritage still underground and building a common understanding of collaboration for the zoning, restoration, 
exhibition of the discovered properties and connecting it to the World Heritage. This role is highly essential to ensure the global promotion and preservation of our natural and cultural assets of universal value, therefore, to pass them down to future generations.

\section{References}

Ahunbay, Zeynep. "UNESCO Dünya Miras Listesi ve Miras Yönetimine Etkisi”. Kültürel Miras Yönetimi, Ed. Asu Aksoy, T.C. Anadolu Üniversitesi Yay., 2012, pp. 125-142.

Akıllı, Erman. "Turksoy, Organization of Turkic States and Cultural Diplomacy: Transactionalism Revisited." bilig, no. 91, 2019, pp. 1-25.

Akyol, Gülsüm, Sefer Çon, Zöhre Polat. "Türkiye'nin Dünya Miras Alanları.” Journal of Travel and Tourism Research, no. 15, 2019, ss. 39-68.

Aliağaoğlu, Alpaslan. "Sosyo-Kültürel Miras Turizmi ve Türkiyeden Örnekler." Ankara Üniversitesi Coğrafi Bilimler Dergisi, vol. 2, no. 2, 2004, pp. 50-64.

Arslan, Sıddık. "Türk Dünyasının Birlikteliğinde Kültürün Rolü.” Turkish Studies. International Periodical for The Languages, Literature and History of Turkish or Turkic, vol. 11, no. 2, 2016, pp. 149-216.

Başlar, Kemal. "Kırkıncı Yılında Dünya Mirası Sözleşmesi (1972-2012)." Uluslararası Hukuk ve Politika, vol. 7, no. 27, 2011, pp. 25-52.

Buyar, Cengiz. "İpek Yolu Üzerinde Tarihî Bir Şehir: Oş." Kirgızistan Araşttrmaları 2019, 2019, pp. 13-42.

Çandarlı Şahin, Aslı "Türk Dünyası ile Kültürel İlişskiler Bağlamında Yapılandırılan Kurum ve Kuruluşlar." Turkish Studies (International Periodical for the Languages, Literature and History of Turkish or Turkic), vol. 12, no. 26, 2017, pp. 81-100.

Deniz, Taşkın, and Doğan Karadağ. "Türk Dünyası'nın Tanıtımında Modern İpek Yolu Ortak Tur Paketi." Türk Turizm Araştırmaları Dergisi / Journal of Turkish Tourism Research, vol. 3, no. 1, 2019, pp. 93-101.

Dönmez, Cengiz, and C. C. Yeşilbursa. "The Effect Of Cultural Heritage Education On Students' Attitudes Toward Tangible Heritage." Elementary Education Online, vol. 13, no. 2, 2014, pp. 425-442.

Dünya Mirası Konvansiyonunun Uygulanmasina Yönelik İslevsel İlkeler, Dünya Mirası Merkezi. http://alanbaskanligi.bursa.bel.tr/wp-content/uploads/2015/07/ Uygulama-Rehberi-2008-TR.pdf, 2008.

Edson Gary. "Heritage: Pride or Passion, Product or Service?" International Journal of Heritage Studies, vol.10, no. 4, 2004, pp. 333-348.

Erol, Mehmet Seyit \& Kadir Ertaç Çelik. "Türk Dünyası'nda İşbirliği Denemesi: Türk Keneşi ve Kazakistan.” [The Cooperation Test in Turkish World: 
Organization of Turkic States and Kazakhstan]. Türk Dünyası Incelemeleri Dergisil Journal of Turkish World Studies, vol. 17, no. 2, 2017, pp. 15-32.

Horata, Osman. “Türk Dünyası'nın Kültürel Ufukları: Tarihsel Bağlam İçinde Genel Bir Değerlendirme.” bilig, no. 82, 2017, pp. 117-131.

Huang, C. H., \& Tsaur, J. R., \& Yang, C. H. "Does World Heritage List Really İnduce More Tourists? Evidence from Macau”. Tourism Management, vol. 33, no. 6, 2010.

ICOMOS Dünya Mirası Kültür Varlıkları için Etki Değerlendirmesi Rehberi. Uluslararasi Anttar ve Sitler Konseyi. January. http://www.alanbaskanligi. gov.tr/evrak/4365kmed-rehberipdf.pdf, 2011.

Işıktaş, Erkan, and Alev Duran. "Geçmişten Günümüze İpek Yolu’nun Önemi ve Buna İlişkin Yapılmış Bilimsel Çalışmalar.” Social Sciences Studies Journal, vol. 3, no. 8, 2017, pp. 584-596.

Kiper, Perihan. Küreselleşme Sürecinde Kentlerin Tarihsel-Kültürel Değerinin Korunmast-Türkiye-Bodrum Örneği. Doktora Tezi. Ankara Üniversitesi, 2004.

Poria, Y., A. Biran, A. Reichel. "Heritage Site Management: Motivations and Expectations." Annals of Tourism Research no. 33, 2006, pp. 162-178.

Purtaş, Fırat. Orta Asya ile Güney Asya Arasında Modern İpek Yolu Projesi. 2011.

Purtaş, Fırat. "Cultural Diplomacy Initiatives of Turkic Republics.” Perceptions, vol. XXII, no 1, 2017, pp. 91-114.

Somuncu, Mehmet, and Turgut Yiğit. "World Heritage Sites in Turkey: Current Status and Problems of Conservation and Management." Coğrafi Bilimler Dergisi, vol. 8, no. 1, 2010, pp. 1-26.

Şakacı, Bilge Kağan. "Doğal ve Kültürel Mirasın Hayati Sorunu: İstisnai Evrensel Değer (UNESCO Dünya Mirası Listesi).” Çankırı Karatekin Üniversitesi SBE Dergisi, vol. 6, no. 1, 2015, pp. 455-472.

Taşağıl, Ahmet. "İpek Yolu'nun Tarihi Temelleri." İpek Yolu-Silkroad-Velikiy Şelkovıy Put, https:/www.ayk.gov.tr/wp-content/uploads/2015/02/\%c4\%b0pekyolusilkroadac.pdf, pp. 2294-2301.

Ürün, Şule. Dünya Kültürel ve Doğal Mirasın Korunmasına Dair Sözleşme: Doğal Miras Alanları Başvuru, Adaylık ve Değerlendirme Süreçleri. Turkey: UNESCO Türkiye Millî Komisyonu Tez Çalışması, 2016.

Yıldız, Sevcan, and Engin Derman. "Kültürel Miras: UNESCO Dünya Mirası Listesi Türkiye Örneği.” Uluslararası Kültürel Miras ve Turizm Kongresi / International Congress On Cultural Heritage and Tourism / ICCHT. May 19-21. 2017, pp. 5-7.

Yılmaz, Murat (Ed.). Türk Dünyası Kültürel Mirası Envanter Çalışması. Ahmet Yesevi Uluslararası Türk-Kazak Üniversitesi Yayınları, 2015. 


\section{Electronic References}

http://www.modernsilkroadtour.com/

http://www.unesco.org.tr/Pages/125/122/UNESCO-Dünya-Miras1-Listesi

https://whc.unesco.org/en/list

https://whc.unesco.org/en/tentativelists/state=az

https://whc.unesco.org/en/tentativelists/state=kg

https://whc.unesco.org/en/tentativelists/state $=\mathrm{kz}$

https://whc.unesco.org/en/tentativelists/state $=$ tr

https://whc.unesco.org/en/tentativelists/state=uz

www.iccrom.org/09.01.2020 ICCROM The International Centre for the Study of

the Preservation and Restoration of Cultural Property

www.icomos.org/12.01.2020 ICOMOS International Council on Monuments and Sites

www.iucn.org/16.01.2020 IUCN International Union for Conservation of Nature www.kulturturizm.gov.tr/12.01.2020 Republic of Turkey Ministry of Culture and Tourism/Dünya Mirasında Türkiye (Turkey on the World Heritage List)

www.kulturvarliklari.gov.tr/18.01.2020 Kültür Varlıkları ve Müzeler Genel

Müdürlüğü (Directorate General of Cultural Assets and Museums)

www.mfa.gov.tr/06.01.2020 Republic of Turkey Ministry of Foreign Affairs

www.turkkon.org/10.12.2021 Türk Devletleri Teşkilatı (Organization of Turkic States)

www.turksoy.org, Uluslararası Türk Kültürü Teşkilatı (TURKSOY) / International

Organization of Turkic Culture.

www.whc.unesco.org/06.01.2020 UNESCO Dünya Miras Merkezi (UNESCO

World Heritage Center) 


\section{Geçmişten Geleceğe Kültürlerin Yakınlaşma Rotasında Türk Devletleri Teşkilatı Ülkelerinin Dünya Mirasına Katkılan*}

\section{Cengiz Buyar** \\ Uğur Ünal ${ }^{* *}$}

Öz

İnsanoğlu tarihi süreçte çok sayıda somut kültürel değer ortaya koymuş, bunların bir kısmı günümüze ulaşmış, bir kısmı da çeşitli sebeplerden dolayı ulaşamamıştır. Bunlardan insanlığın ortak geçmişinin bir parçası olan kültür değerlerine Dünya Mirası denilmektedir. UNESCO 1972 yılından beri tüm insanlığın ortak değeri kabul edilebilecek kültürel ve doğal miras alanlarını, Dünya Mirası Listesi'ne almakta ve bu alanların korunması için çalışmaktadır.

UNESCO Dünya Kültür Mirası Listesi çalışmasıyla, insanlığın kaybetmek üzere olduğu değerleri tekrar görünür ve kalıcı kılarak önemli bir görevi yerine getirmektedir. 2019 yılı itibariyle UNESCO Dünya Mirası Listesi'nde 1121 miras bulunmaktadır. Bu çalışmada Türk Devletleri Teşkilatı'nda yer alan ülkelerin sahip olduğu kültürel ve doğal miraslar UNESCO'nun belirlemiş olduğu on temel kriter üzerinden istatistiksel ve betimsel analiz yöntemleri kullanılarak ele alınmıştır. Böylelikle Dünya Kültür Mirası Listesi'nde yer alan Türk dünyasının kültürel ve doğal miraslarının bir arada ele alınması, farkındalık oluşturacak bir bakış açısıyla değerlendirilmesi amaçlanmıştır.

\section{Anahtar Kelimeler}

Kültür, Dünya Kültür Mirası Listesi, UNESCO, Türk Dünyası, Türk Devletleri Teşkilatı.

\footnotetext{
Geliş Tarihi: 04 Şubat 2020 - Kabul Tarihi: 04 Şubat 2021

Bu makaleyi şu şekilde kaynak gösterebilirsiniz:

Buyar, Cengiz, ve Uğur Ünal. "Contribution of Organization of Turkic States Members to World Heritage at a Time of Cultural Convergence from the Past to the Future.” bilig, no. 100, 2022, ss. 1-35.

** Doç. Dr., Kırgızistan-Türkiye Manas Üniversitesi, Edebiyat Fakültesi, Tarih Bölümü - Bişkek / Kırgızistan ORCID: 0000-0002-0549-4463

cengiz.buyar@manas.edu.kg

Do* Doç. Dr., Kırgızistan-Türkiye Manas Üniversitesi, İletişim Fakültesi, Halkla İlişkiler ve Reklamcılık Bölümü - Bişkek / Kırgızistan

ORCID: 0000-0003-0294-0082

ugur.unal@manas.edu.kg
} 


\title{
Вклад стран Организации тюркских государств в мировое наследие в контексте сближения культур
}

\author{
Дженгиз Буяр \\ Угур Унал
}

\begin{abstract}
Аннотация
За всю историю человечества было создано множество материальных и культурных ценностей, дошедших до наших дней, а также утраченных по разным причинам. Ценности, являющиеся частью всеобщей истории человечества, называются Всемирным наследием. С 1972 года ЮНЕСКО вводит в Список всемирного наследия объекты культурного и нематериального наследия, которые могут считаться общей ценностью всего человечества, и работает над их защитой.

Благодаря Списку всемирного наследия, ЮНЕСКО выполняет важную задачу, а именно восстанавливает объекты, находящиеся на грани исчезновения и придает им былую значимость. По состоянию на 2019 год в Список всемирного наследия ЮНЕСКО входит 1121 объект. В данном исследовании культурное и нематериальное наследие стран, входящих в Организацию тюркских государств, было рассмотрено с использованием методов статистического и описательного анализа по десяти основным критериям, определенным ЮНЕСКО. Таким образом, исследование направлено на изучение культурного и нематериального наследия тюркского мира, включенного в Список ЮНЕСКО, их оценку и повышение осведомленности.
\end{abstract}

\section{Ключевые слова}

Культура, Список всемирного культурного наследия, ЮНЕСКО, тюркский мир, Организация Тюркских Государств

* Поступило в редакцию: 04 февраля 2020 г. - Принято в номер: 04 февраля 2021 г.

Ссылка на статью:

Buyar, Cengiz, and Uğur Ünal. "Contribution of Organization of Turkic States Members to World Heritage at a Time of Cultural Convergence from the Past to the Future." bilig, no. 100, 2022, pp. 1-35.

** Доц., д-р, Кыргызско-Турецкий университет «Манас», Гуманитарный факультет, Отделение истории - Бишкек / Кыргызстан.

ORCID: 0000-0002-0549-4463

cengiz.buyar@manas.edu.kg

*** Доц., д-р., Кыргызско-Турецкий университет «Манас», Факультет коммуникации, Отделение связей с общественностью и рекламного дела - Бишкек / Кыргызстан.

ORCID: 0000-0003-0294-0082

ugur.unal@manas.edu.kg 
